\title{
Purification and characterization of an $\alpha$-L-arabinofuranosidase from Streptomyces lividans 66 and DNA sequence of the gene (abfA)
}

\author{
Catherine MANIN, François SHAREEK, Rolf MOROSOLI and Dieter KLUEPFEL* \\ Centre de recherche en microbiologie appliquée, Institut Armand-Frappier, Université du Québec, 531 boulevard des Prairies, Laval-des-Rapides, Québec, \\ Canada H7N $4 Z 3$
}

\begin{abstract}
The gene encoding an $\alpha$-L-arabinofuranosidase (abfA) was homologously cloned in Streptomyces lividans and its DNA sequence was determined. The enzyme was purified from the cytoplasm of the hyperproducing clone $S$. lividans IAF116. Its $M_{\mathrm{r}}$ was estimated by gel filtration and found to be approx. 380000. Since SDS/PAGE indicated a native protein of $M_{\mathrm{r}}$ 69000 , it can be concluded that the native protein consists of several subunits of that size. The pI value was 4.6. The kinetic constants determined with $p$-nitrophenyl $\alpha$-L-arabinofuranoside as substrate were a $V_{\max }$ of $180 \mathrm{units} / \mathrm{mg}$ of protein and a $K_{\mathrm{m}}$ of $0.6 \mathrm{mM}$. The specific activity of the purified enzyme on this substrate was 153 units/mg of protein. Optimal enzyme activity
\end{abstract}

was obtained at $60^{\circ} \mathrm{C}$ and $\mathrm{pH} 6.0$. The enzyme cleaved $p$ nitrophenyl $\alpha$-L-arabinofuranoside, but had no activity on a variety of other $p$-nitrophenyl glycosides, except on $p$-nitrophenyl $\beta$-D-xylopyranoside. The enzyme showed no activity on oatspelts (Avena sativa) xylan or arabinogalactan, but acted on beet (Beta) arabinan or arabinoxylan. Hydrolysis occurred on arabino-oligoxylosides obtained from oat-spelts xylan after digestion with xylanases. Since $S$. lividans normally does not secrete arabinofuranosidase, this enzyme may play a role in the assimilation of arabinose moieties from arabinose-containing xylo-oligosaccharides generated by $\beta$-xylosidases or xylanases.

\section{INTRODUCTION}

L-Arabinose residues are found widely distributed among many heteropolysaccharides of different plant tissues. They constitute monomeric and/or oligomeric side chains on $\beta$-1,4-linked xylose or galactose backbones in xylans, arabinoxylans and arabinogalactans and are the core in arabinans forming $\alpha$-1,5-linkages (Ward and Moo-Young, 1989). These side chains may restrict the enzymic hydrolysis of hemicelluloses in different applications of hemicellulases, such as in the improvement of digestibility of animal feed by ruminants (Brice and Morrison, 1982) or biobleaching of wood pulps (Wong et al., 1988). Enzymes which cleave $\alpha$-L-arabinofuranosidic linkages are arabinosidases which include $\alpha$-L-arabinofuranosidases (AFs; EC 3.2.1.55), that hydrolyse terminal non-reducing $\alpha-\mathrm{L}-1,2-$ or $\alpha$-L-1,3-arabinofuranosyl residues from xylans, arabinoxylans and arabinogalactans, and endo-1,5- $\alpha$-L-arabinanases (EC 3.2.1.99), which hydrolyse $\alpha$-L-1,5-arabinofuranosidic linkages from arabinans (Dekker and Richards, 1976; Kaji, 1984). $\alpha$-L-AFs are also involved in the hydrolysis of grape monoterpenyl glycosides during wine fermentation (Gunata et al., 1989).

L-AFs have been purified and characterized from fungi such as Aspergillus niger (Kaji et al., 1969; Rombouts et al., 1988), Corticium rolfsii (Kaji and Yoshihara, 1970), Trichoderma reesei (Poutanen, 1988) and Dichomitus squalens (Brillouet et al., 1985). These enzymes have also been isolated from bacteria such as Bacillus subtilis (Weinstein and Albersheim, 1979), Clostridium acetobutylicum (Lee and Forsberg, 1987), Ruminococcus albus (Greve et al., 1984), Butyrivibrio fibrisolvens (Hespell and O'Bryan, 1992) and Streptomyces sp. (Kaji et al., 1981; Komae et al., 1982; Tajana et al., 1992).
In our studies on hemicellulases from Streptomyces lividans, we have homologously cloned several xylanase, $\beta$-mannanase and cellulase genes by a shot-gun cloning from a gene bank prepared by partial digestion of the chromosome (Mondou et al., 1986; Shareck et al., 1987, 1991; Théberge et al., 1992; Arcand et al., 1993). The same gene bank was used to screen for genes coding for various debranching enzymes related to the xylanolytic system. In the present paper we describe the cloning and DNA sequence of an $\alpha$-L-AF gene ( $a b f A$ ) as well as the purification and characterization of the enzyme produced by clone $S$. lividans IAF116.

\section{MATERIALS AND METHODS}

\section{Organisms}

Streptomyces lividans 66 strain 1326 was obtained from D. A. Hopwood (John Innes Institute, Norwich, U.K.). The host strain used for cloning was a xylanase- and cellulase-negative mutant, $S$. lividans IAF10-164, obtained by mutagenesis with $N$-methyl$N$-nitro- $N$-nitrosoguanidine (Mondou et al., 1986). The multicopy plasmid pIJ702, which served as cloning vector, was kindly supplied by Dr. E. Katz (Katz et al., 1983).

\section{Cloning of the $\alpha$-L-AF gene}

The $\alpha$-L-AF gene was isolated from a homologous gene bank previously constructed in a xylanase- and cellulase-negative mutant $S$. lividans IAF10-164 and containing approx. 25000 clones (Mondou et al., 1986). The screening was carried out on solid agar TSB medium (Difco Laboratories, Detroit, MI, U.S.A.) by spraying with $1 \mathrm{mM}$ 4-methylumbelliferyl $\alpha$-L-

\footnotetext{
Abbreviations used: abfA, gene coding for $\alpha$-L-arabinofuranosidase (AF); DTT, dithiothreitol; $p$-NP, $p$-nitrophenol; TSB, tryptic soy broth; ORF, open reading frame.

* To whom correspondence and reprint requests should be addressed.

The nucleotide sequence data reported in this paper will appear in the GenBank, EMBL and DDBJ Nucleotide Sequence Databases under the accession number U04630.
} 
arabinofuranoside (Sigma Chemical Co., St. Louis, MO, U.S.A.). The AF-expressing clones were identified under u.v. light by their fluorescence after $10 \mathrm{~min}$ of incubation at $37^{\circ} \mathrm{C}$ in the dark.

\section{DNA manipulations and sequencing}

All DNA manipulations in $S$. lividans were carried out as described by Hopwood et al. (1985). Single-stranded DNA was prepared using M13mp18 and M13mp19 phages and E. coli DH11S as described by Sambrook et al. (1989). The nucleotide sequence of both strands were determined by the dideoxy chaintermination method of Sanger et al. (1977) using Sequenase (USB Biochemicals) and analysed on a Pharmacia automatic sequencer using the ALF Manager program. To fill the remaining gaps, custom oligonucleotide primers were synthesized with a Gene Assembler Plus (Pharmacia-LKB). DNA sequences were assembled and analysed using the Pustell Sequence Analysis Programs of International Biotechnologies Inc. (New Haven, CT, U.S.A.). A homology search with sequences in the Genbank/EMBL databases was carried out with the software package of the Genetics Computer Group programs installed on a VAX computer at the Université de Montréal.

\section{Culture conditions}

The cultivation of the strains was carried out as previously described by Kluepfel et al. (1990). For large-scale enzyme production, 2-litre Erlenmeyer flasks containing $400 \mathrm{ml}$ of modified M13 medium were used. The medium contained oatspelts xylan (Sigma; $4 \mathrm{~g}),\left(\mathrm{NH}_{4}\right)_{2} \mathrm{SO}_{4}(1.4 \mathrm{~g}), \mathrm{K}_{2} \mathrm{HPO}_{4}(5.5 \mathrm{~g})$, $\mathrm{KH}_{2} \mathrm{PO}_{4}(1.0 \mathrm{~g}), \mathrm{MgSO}_{4}, 7 \mathrm{H}_{2} \mathrm{O}(0.3 \mathrm{~g}), \mathrm{CaCl}_{2}, 2 \mathrm{H}_{2} \mathrm{O}(0.3 \mathrm{~g})$ and Tween $80(2 \mathrm{ml})$ in 1 litre of distilled water; $1 \mathrm{ml}$ of a trace-metal solution, containing $\mathrm{CoCl}_{2}, 6 \mathrm{H}_{2} \mathrm{O}(200 \mathrm{mg}), \mathrm{FeSO}_{4}, 7 \mathrm{H}_{2} \mathrm{O}$ $(500 \mathrm{mg}), \mathrm{MnSO}_{4}, \mathrm{H}_{2} \mathrm{O}(160 \mathrm{mg})$ and $\mathrm{ZnSO}_{4}, 7 \mathrm{H}_{2} \mathrm{O}(140 \mathrm{mg})$, in $100 \mathrm{ml}$ of distilled water, was added. $\mathrm{CaCl}_{2}$ and $\mathrm{MgSO}_{4}$ were added aseptically after sterilization to prevent the formation of precipitates. The cultures were incubated at $34^{\circ} \mathrm{C}$ on a rotary shaker at $240 \mathrm{rev} . / \mathrm{min}$ for $48 \mathrm{~h}$. The inoculum size was $6 \%(\mathrm{v} / \mathrm{v})$ and was obtained from a vegetative tryptic-soy-broth (TSB) culture.

\section{Enzyme recovery}

The fermentation broth was centrifuged for $30 \mathrm{~min}$ at $4{ }^{\circ} \mathrm{C}$ and $10000 \mathrm{~g}$. The mycelium was washed, then suspended in an equal volume of $50 \mathrm{mM}$ sodium phosphate $(\mathrm{pH} 6.8) / 0.5 \mathrm{mM}$ dithiothreitol (DTT) $/ 1.0 \mathrm{mM}$ EDTA $/ 0.5 \mathrm{mM}$ phenylmethanesulphonyl fluoride. The cells were disrupted by two successive passages through a French pressure cell operated at $96.6 \mathrm{MPa}$ $\left(14000 \mathrm{lbf} / \mathrm{in}^{2}\right)$. The resulting suspension was centrifuged at $4{ }^{\circ} \mathrm{C}$ and $24000 \mathrm{~g}$ for $30 \mathrm{~min}$. The supernatant represented the cytoplasmic fraction containing the enzyme activity.

\section{Enzyme purification}

$\left(\mathrm{NH}_{4}\right)_{2} \mathrm{SO}_{4}$ was slowly added, with stirring, to the cytoplasmic fraction to $35 \%$ saturation level at $4{ }^{\circ} \mathrm{C}$. The mixture was stirred for another $60 \mathrm{~min}$, and the resulting precipitate was removed by centrifugation at $4{ }^{\circ} \mathrm{C}$ and $10000 \mathrm{~g}$ for $30 \mathrm{~min}$. The supernatant was adjusted to $65 \%$ satn., stirred, then centrifuged as described above. The pellet was dissolved in $20 \mathrm{mM}$ piperazine (pH 6.0)/0.5 mM DTT/1.0 M ( $\left.\mathrm{NH}_{4}\right)_{2} \mathrm{SO}_{4}$ and loaded on to a column $(5 \mathrm{~cm} \times 15 \mathrm{~cm})$ packed with phenyl-Sepharose CL-4B (Pharmacia). The column was previously equilibrated with the same buffer and then eluted at a rate of $2.0 \mathrm{ml} / \mathrm{min}$ with a decreasing gradient of $1.0-0 \mathrm{M}\left(\mathrm{NH}_{4}\right)_{2} \mathrm{SO}_{4}$. Active fractions were collected, pooled, passed through a low-protein-binding Acro Disc filter $(0.45 \mu \mathrm{m}$ pore size; Gelman Science, Ann Arbor, MI, U.S.A.) and absorbed directly on to a semi-preparative anionexchange h.p.l.c. column (Protein-Pak DEAE 5 PW; WatersMillipore, St. Laurent, Qué., Canada) which had been equilibrated with $20 \mathrm{mM}$ piperazine (pH 6.0)/0.5 mM DTT. The enzyme was eluted in the same buffer with a linear gradient of $0.1-1.0 \mathrm{M} \mathrm{NaCl}$. The active fractions were pooled, concentrated and desalted in $0.1 \mathrm{M}$ sodium phosphate (pH 7.0)/0.5 mM DTT by ultrafiltration with in a Centriprep concentrator 100 (100000$M_{\mathrm{r}}$ nominal cut-off; Amicon Division, Danvers, MA, U.S.A.). Final purification was carried out by gel filtration on two h.p.l.c. columns in series (Protein Pak 300 SW; Waters-Millipore). The columns were previously equilibrated with $0.1 \mathrm{M}$ sodium phosphate buffer $(\mathrm{pH} 7.0) / 0.5 \mathrm{mM}$ DTT and then eluted with the same buffer at an elution rate of $0.5 \mathrm{ml} / \mathrm{min}$. AF-containing fractions were pooled and concentrated by ultrafiltration. All the enzyme purification steps were carried out at room temperature. The purified $\alpha$-L-AF was stored at $-70{ }^{\circ} \mathrm{C}$ after addition of glycerol to a final concentration of $5 \%$.

\section{Enzyme assays}

The assay solution contained $2 \mathrm{mM} \quad p$-nitrophenyl $\alpha$-Larabinofuranoside as substrate in $0.4 \mathrm{ml}$ of $0.1 \mathrm{M}$ Mcllvaine buffer, $\mathrm{pH}$ 6.0. The reaction was initiated by addition of $0.02 \mathrm{ml}$ of appropriately diluted enzyme, incubated for $10 \mathrm{~min}$ at $60^{\circ} \mathrm{C}$ and terminated by addition of $0.6 \mathrm{ml}$ of $1.0 \mathrm{M} \mathrm{Na}_{2} \mathrm{CO}_{3}$. The absorbance of this mixture was determined at $400 \mathrm{~nm}$ and converted into $\mu \mathrm{mol}$ of $p$-nitrophenol ( $p$-NP) released, calculated from a standard curve with known concentrations of this compound. The enzyme activity was expressed in units, where 1 unit is the amount of enzyme that releases $1 \mu \mathrm{mol}$ of $p$ $\mathrm{NP} / \mathrm{min}$. AF assays on polysaccharide were carried out at substrate concentration of $1 \%$ (suspended in $0.1 \mathrm{M}$ Mcllvaine buffer, $\mathrm{pH} 6.0$, to which $1 \mu \mathrm{g}$ of enzyme was added and incubated at $37^{\circ} \mathrm{C}$ for $16 \mathrm{~h}$, followed by h.p.l.c. analysis. Substrates used in these assays were oat-spelts xylan (Sigma), rye- and wheat-flour arabinoxylan (Megazyme Ltd., Sydney, Australia), arabinogalactan (Sigma), and linear and debranched arabinan (Megazyme). AF assays were carried out with arabinooligoxylosides at concentrations of $50 \mathrm{mM}$, to which $1 \mu \mathrm{g}$ of enzyme was added, and the mixture incubated at $37^{\circ} \mathrm{C}$ for $2 \mathrm{~h}$, followed by t.l.c.

\section{Protein}

The protein content of enzyme preparations was determined as described by Lowry et al. (1951), using BSA fraction V (Sigma) as standard.

\section{Determination of isoelectric point}

Analytical isoelectric focusing was carried out on PhastGel containing Pharmalyte carrier ampholytes in the $\mathrm{pH}$ range 3-10 using the PhastSystem. The gels were silver-stained after the run. (Pharmacia-LKB Separation and Development Technique Files nos. 100 and 210).

\section{Determination of $\boldsymbol{M}_{\mathbf{r}}$}

The $M_{\mathrm{r}}$ of the purified AF was estimated by SDS/PAGE using the PhastSystem. The protein bands were detected by silver staining (Pharmacia-LKB Separation and Development Tech- 
nique Files nos. 111 and 210). The $M_{\mathrm{r}}$ of the native protein was determined by using two Pharmacia Superose 6 HR 10/30 columns in series, calibrated with standard proteins (Sigma Kit

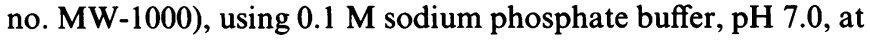
a flow rate of $0.5 \mathrm{ml} / \mathrm{min}$.

\section{Purification of arabino-oligoxylosides}

A digest of oat-spelts xylan by xylanases B and C (Kluepfel et al., $1990,1992)$ was passed through a column of Bio-Gel P-2 (200-400 mesh) (Bio-Rad Laboratories, Mississauga, Ont., Canada) using water as eluent at a flow rate of $1 \mathrm{ml} / \mathrm{min}$ and at $50{ }^{\circ} \mathrm{C}$ (John et al., 1969). The different fractions were collected and freeze-dried. Linear oligoxylosides and branched arabino-oligoxylosides were separated by preparative paper chromatography on Whatman 3MM paper using the solvent system butanol/pyridine/water ( $6: 4: 3$, by vol.), by the descending method. The oligosaccharides were detected with aniline/hydrogen phthalate reagent. The corresponding bands were cut out, the sugars were eluted in water, and then freeze-dried. Their $M_{\mathrm{r}}$ values were determined by fast-atom-bombardment m.s. by Dr. O. A. Mamer (Biomedical Mass Spectrometry Unit, McGill University, Montréal, Qué., Canada).

\section{Analysis of oligosaccharides}

Mixture of oligosaccharides were analysed either by h.p.l.c. on an Aminex HPX-42A column (Bio-Rad) at $80^{\circ} \mathrm{C}$ with water as eluent at a flow rate of $0.5 \mathrm{ml} / \mathrm{min}$, or by t.l.c. on microcrystalline cellulose plates (Merck, Darmstadt, Germany) in the solvent system butanol/pyridine/water ( $6: 4: 3$, by vol). Reducing sugars were revealed with aniline/hydrogen phthalate reagent.

\section{Antibodies and Western immunoblotting}

Antibodies were raised against AF in New Zealand White rabbits by injecting $100 \mu \mathrm{g}$ of pure enzyme combined with complete Freund's adjuvant, followed by three additional injections of $200 \mu \mathrm{g}$ of AF in incomplete Freund's adjuvant at intervals of 1,2 and 7 weeks respectively. Western blotting was carried out using anti-AF antibodies coupled to ${ }^{125}$ I-Protein A (Amersham Canada Ltd., Oakville, Ont., Canada) as previously described (Mondou et al., 1986)

\section{RESULTS}

\section{Cloning of the $\alpha$-L-AF gene}

Screening of a gene bank of Streptomyces lividans, constructed in $S$. lividans IAF10-164 as described by Mondou et al. (1986), resulted in the isolation of two clones showing $\alpha$-L-AF activity. These clones harboured plasmids pIAF112 and pIAF116, which had chromosomal DNA insertions of $7.8 \mathrm{~kb}$ and $11.4 \mathrm{~kb}$ respectively. The insert's size was reduced by KpnI and PstI digestions respectively, and led to plasmids pIAF113 and pIAF117 (Figure 1). Transformation of S. lividans IAF10-164 with these plasmids gave AF-positive clones. Southern hybridization with a $3.2 \mathrm{~kb} K p n I-P s t$ I fragment from pIAF116 revealed identical sequences in all the clones (results not shown). Restriction fragments from plasmid pIAF116 served for the determination of the DNA sequence of the $a b f$ A gene. AF activity was determined for each clone and compared with that of the wild-type $S$. lividans 1326 and the mutant $S$. lividans IAF10-164 serving as host strain. All clones showed improved enzyme production (Table 1). S. lividans IAF116 produced AF at a level
48 times that of the wild type, and therefore was chosen for further enzyme purification.

\section{Nucleotide-sequence analysis}

The abfA gene was located on the $3.2 \mathrm{~kb}$ Pst I--KpnI fragment in plasmid pIAF116 (Figure 1). This fragment and the internal Sall fragments were subcloned into M13mp18 and M13mp19 and the nucleotide sequence was determined for both strands. The last
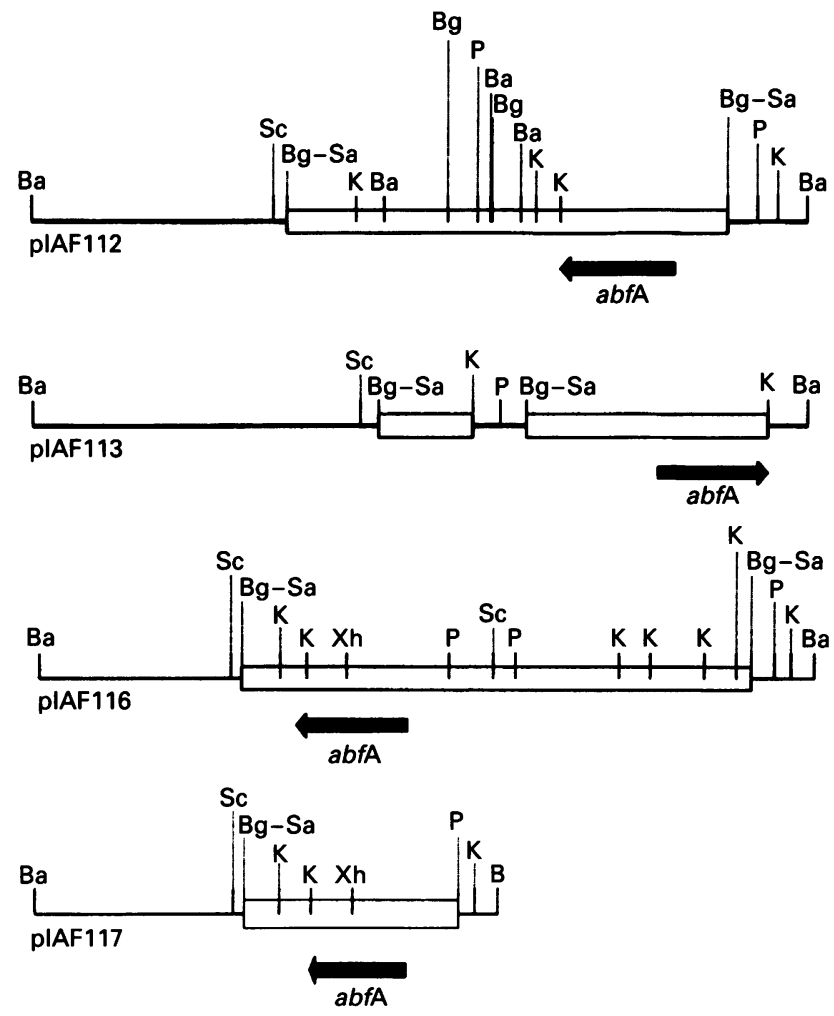

Figure 1 Restriction maps of plasmids pIAF112, PIAF113, PIAF116 and pIAF117

The open boxes represent the inserts cloned into plasmid plJ702 (thin line). The arrow marked $a b f A$ indicates the orientation of the $a b f A$ structural gene. Restriction endonucleases: $B a$, BamHI; Bg, Bg/ll; K, Konl; P, Pstl; Sc, Sacl; Sa, Sau3A; Xh, Xhol.

Table 1 Comparison of intracellular $\alpha$-L-arabinofuranosidase activity of wild-type Streptomyces lividans 1326 and mutant S. lividans IAF10-164 and the clones carrying abfA recombinant plasmids pIAF112, pIAF113, pIAF116 and pIAF117 after cultivation in submerged cultures for $\mathbf{4 8 h}$

\begin{tabular}{ll}
\hline $\begin{array}{l}\text { Streptomyces } \\
\text { lividans } \text { strain }\end{array}$ & $\begin{array}{l}\text { Activity (units/ } \\
\mathrm{mg} \text { of protein) }\end{array}$ \\
\hline 1326 (wild-type) & \\
3131 (wild-type + plJ702) & 0.05 \\
IAF10-164 $\left(x / n^{-}, \mathrm{ce}^{-}\right)$ & 0.07 \\
IAF112 & $\mathrm{ND}^{\star}$ \\
IAF113 & 0.26 \\
IAF116 & 0.84 \\
IAF117 & 2.41 \\
\end{tabular}

* ND, not detectable. 
s.*

GG CCG GGC GCC TEA TGG CCG GCC TGC CGC TGA TCG TCG TCT TCG TCT 47 TCT TCC AGC GCC AGA TCG TGG CGG CGT CGC CCA CAC GGC CTG GCC GGC 95 CAG TAG CCC CTC ACC CCG TCC CGA MAS CM MG ATS CGC ACC GCC CGC 143 TTC ACC CTC GAC CCC GCC TTC ACC GTC GGC GCC GTC MLC CCC CGT CTC 191 TTC GGC TCC TTC GTC CAM CAC CTC GG CGC TGC GTG TAC ACC GGC GTC 239 PIC GGC TCC TTC GiC GA CAC CIC GGA CGC TGC GTG TAC ACC GGC G $V_{V}$

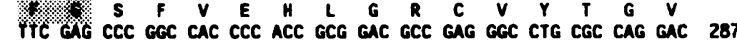

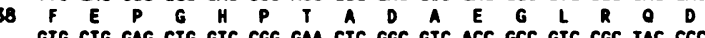
GTG CTS GAG CTG GTC CGG COA CTC GGC GTC ACC GCC GTC CGC TAC CCC 33

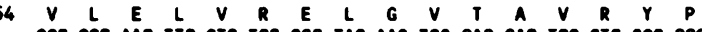
GGC GGC MAC TTC GTC TCC GGC TAC MG TGG GAG GAC TCG GTC GGC CCG 383 $G$ G N F V $S$ S G $Y$ K W E GTG GAG GAC CGT CCG CGC CGC CTC GAC CTG GCC TGG CGC TCC ACC GAG 431

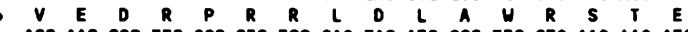
ACC MC CGC TTC GGC CTC ICC GAG TAC ATC GCC ITC CTG MG MG ATC 479

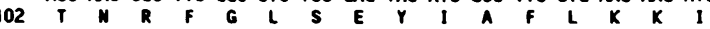
GGC CCG CAG GCC GAG CCC ATG ATG GCG GTC MAC CTC GGC ACC CGC GGC 527

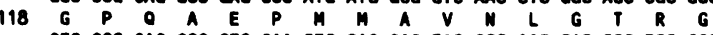
GTC OCC GAG GCG CTC GM CTC CAG GAG TAC GCC MAC CAC CCC TCC GGC 573

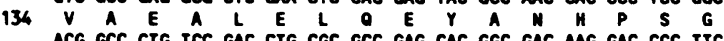
150 ACG GCC CTG TCC GAC CTG CGC GCC GAG CAC GGC GAC MG GAC CCC ITC 623

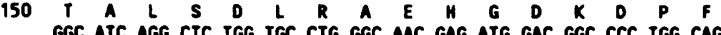
$166 \mathrm{G}$ A ACC GGC CAC MAG ACC GCC GAG GAG TAC GGC CGC GTC GCC GCC GAG ACC 719

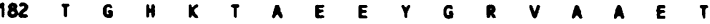
GCC CGC GCC ATG COC CAG ATC GAC CCG GAC GTC OM CTG GTC GCG TGC 767 $198 A R A M A$ O I D P D V E L V A C GGG TCG TCC GGG CAG TCC ATG GAG ACC TTC GCC GAG TGG GAG GCG ACG 815

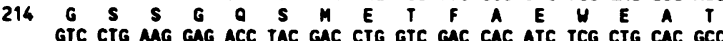
$230 \checkmark v$ GTC GAG ACC TAC GAC CIG GTC GAC CAC ATC TCG CTG CAC GCC TAC TAC GAG CCC CAC GAC OGG GAC GTC GAC TCC TIC CTC GCC ICC GCC 911 246 Y Y E P H D G D V D $S$ F $L A S S A$ 262 GT GAC ATG GAG TCG TTC ATC GAG MAC GTC GTC GCC ACC TGC GAC CAC GTC GGC GCC CGC CTC MG IC E

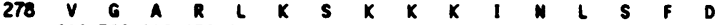
GAG TGS MMC GTC TGG TAC ATG ACC MMG ACG CAG GCC GAG GTC AGC GCC 1055 E W N V W Y

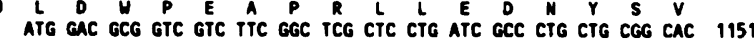

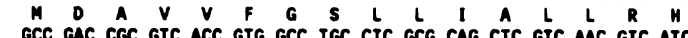

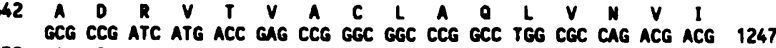
$358 A_{P} I_{M} T_{E} P_{G} G P_{P} A_{Q} T_{T}$ ast

TIC TTC CCC ITC TCC CAG GCC TCG Mag TAC GGC CGC GGC Gag GTC CTC 1295 374 F F P F S O A S K Y G R G E V L GAC GTC CGC GTG GAC TCC CCG ACG TAC GAC ACC GCG MAG TAC GEC GAG 1343

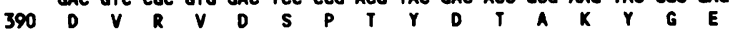
GCC GAC CTG CTG CAC GCC ACC GCC GTG GTG CGC GCC AGA CGC TCG GTC 1391 $406 A$ D L L H A T $V$ V R A R R S V ACC GTC TIC GCC GTC MAC CGC TCG CGC ACC GGG GCC CTC CCG CTG GAG 1439 $422 T V F$ A V M R S R T G A L P L E GTC GCC CTG AGC GGC CTG GAG CTG ACC GAG GTC GTC GAG CAC AGC GCC 1487

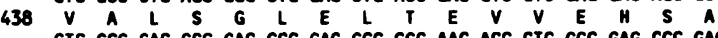
CTC GCG GAC GCC GAC CCC GAC GCC CGC MAC ACC CTC GCC GAG CCC GAG 1535

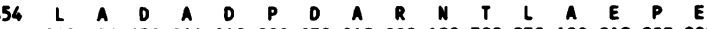
CGC GTC GTC CCG CAC CCG GTC GAC GGC ACC TCC CTG AGG GAC GGC CGG 1583

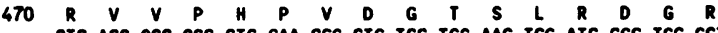
CTC ACC GCC GCC CTG GM CCG CTG TCC TGG MAC TCG ATC CGC TGC GCT 1631 $486 L$ GAC CCG GCC CCG GGT CAG CCG CCG CGC CGG CCG GGG GAG GGG ACG GGC 1679 502 D $P$ P $A$ A TTC ACC GGC ACT CCT CCG GCC GCG CCG CCC AGC AGC TCC AGC GCA CCG 1727 518 F T G T P $P$ A $A$ P $P$ S $S$ S $S A$ CGC CCG GAC CCG ACG GCG CGC CGT TCG CCG GAC AGG ACC GCG AGG GCC 1T75

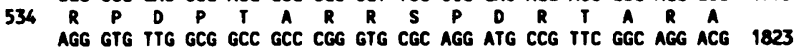
550 AGG GTG TTG GCG GCC GCC CGG GTG CGC AGG ATG CCG ITC GGC AGG ACG MG GTG IGC GGG GCA CCC GTG CGG CCG CCC ACG IAC GCG CCC AGG TTC 1871

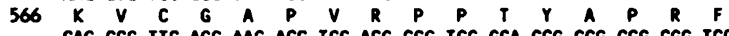
CAG CCG IIC AGG MAG ACC TGG ACG CGG TGG GCA CCG GCG CCG CGG TCC 1919

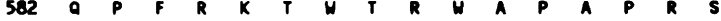
S CCG TCC AGG CGC AGC CCC ACC CAG GCG TCG ATC CCC GEC GES

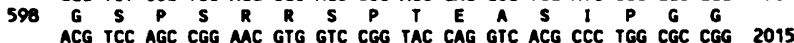

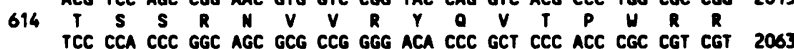

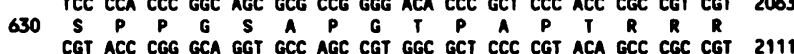
CGT ACC CGG GCA GGT GCC AGC CGT GGC GCT CCC CGT ACA GCC CGC CGT 2111

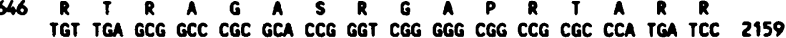
$662 \mathrm{C}$

GCC AGC GCA CCT CGG GCG AGG COC CCT CGA ACG CCG CCG ACG TCA GCC 2207 CGC GGG CCT CCC GGT ACG CGT CCT GGC CGT GCT GTG TGC GCC GCA CCA 225 GGA CGG ACA GGA CGG GGC CGT CGT CCC CTT CGC CGC CCT TGC TCC CCC 2303 CGC CCG CCC TGC TCC CGG CGG CCC GAC GCA GTG CGG CGC GCA GGT CCT 2351 CCG GCA GCC CGA ACG CGG CGT GCC GGT CCA CGT GCC CTI CCC GTC GCC 2399 CGC CCC GTC CGG CTG GTG GCT GCC CAG CGG CAC CCC GTC CAG CCA GGC 2447 CAT CAG CAG GCC GTC CGC GCC CGT GCT GTA CGC GAG GGA CAC CCG CTC 2495 CAG CCC CGT GGC GCC GGT GAG GCG GGC GC

Figure 2 Nucleotide sequence and deduced amino acid sequence of abfa

The amino acids that are identical with the $\mathrm{N}$-terminus of the protein are shaded (residues 1-23). The putative ribosome-binding site is shown in bold face.

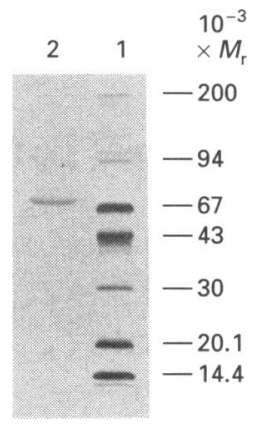

Figure 3 Silver-stained SDS/PAGE (12.5\% polyacrylamide gel) of purified $\alpha-L-A F$

Lane 1, standard protein markers: $\beta$-amylase $\left(M_{\mathrm{r}} 200000\right)$, phosphorylase $b$ (94000), BSA $(67000)$, ovalbumin $(43000)$, carbonic anhydrase $(30000)$, soybean trypsin inhibitor $(20100)$ and $\alpha$-lactalbumin (14400); lane 2 , purified $\alpha$-L-AF.

41 amino acids of the $\mathrm{C}$-terminal end of the protein were beyond the KpnI site and were deduced from the nucleotide sequence of the $0.6 \mathrm{~kb} \mathrm{KpnI}$ fragment isolated from plasmid pIAF116. Figure 2 shows the nucleotide sequence of $a b f$ A. An open reading frame (ORF) starts at an ATG codon located at nt 128 and stops at the TGA codon at nt 2117. This $1986 \mathrm{nt}$ ORF encodes a protein of 662 amino acids totalling $72492 \mathrm{Da}$. This value is close to the $M_{\mathrm{r}}$ of the purified protein estimated by SDS/PAGE (Figure 3). As reported for many genes from streptomycetes, the base composition of the coding region is $73.5 \%$ rich in $\mathrm{G}+\mathrm{C}$ and the third base of the codon is highly biased $(95 \%)$ in favour of $\mathrm{G}$ or $\mathrm{C}$ (Wright and Bibb, 1992). Accordingly, 17 codons out of 61 are unused, and eight are used only once. The first 23 amino acids of the $\mathrm{N}$-terminus of the purified intracellular protein were determined (shaded amino acid residues in Figure 2) using the Edman degradation method (carried out by F. Dumas, Biotechnology Research Institute, Montréal, Qué., Canada). These results enabled us to validate the nucleotide sequence. The putative ORF is preceded by a potential ribosome-binding site (AGGA) located $8 \mathrm{nt}$ upstream of the starting ATG codon.

A search through the Genbank and EMBL Nucleotide Sequence Databases using FASTA software showed no significant similarity with other AF genes already sequenced, namely the $x y n C$ gene from Pseudomonas fluorescens, which encodes the XylC protein (Kellett et al., 1990), and the $x y / B$ gene of Butyrivibrio fibrisolvens (Utt et al., 1991).

\section{Production and isolation of $\alpha$-L-AF}

The $\alpha$-L-AF was produced in submerged cultures with clone Streptomyces lividans IAF116 using the mineral-salt medium M13 containing $1 \%$ oat-spelts xylan as carbon source. Optimal enzyme levels of $1 \mathrm{unit} / \mathrm{mg}$ of total protein were reached after $48 \mathrm{~h}$ of incubation. Crude cell extracts were prepared by disruption of the mycelium in a French press. More than $90 \%$ of 
Table 2 Purification of an $\alpha$-L-arabinofuranosidase from S. lividans IAF116

\begin{tabular}{llccr}
\hline $\begin{array}{l}\text { Purification } \\
\text { step }\end{array}$ & $\begin{array}{l}\text { Total activity } \\
\text { (units) }\end{array}$ & $\begin{array}{l}\text { Total } \\
\text { protein (mg) }\end{array}$ & $\begin{array}{l}\text { Specific activity) } \\
\text { (units/mg of protein) }\end{array}$ & Yield (\%) \\
\hline Cytoplasmic extract & 2826 & 1970.0 & 1 & 100 \\
$\left(\mathrm{NH}_{4}\right)_{2} \mathrm{SO}_{4}$ & 2595 & 1590.0 & 2 & 92 \\
Phenyl-Sepharose CL-4B & 2116 & 158.0 & 13 & 75 \\
DEAE-Sepharose & 1307 & 17.8 & 73 & 46 \\
Gel filtration & 581 & 3.8 & 153 & 21
\end{tabular}

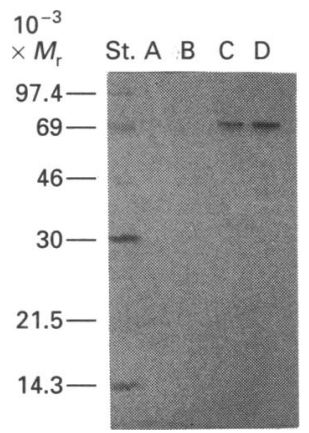

Figure 4 Western-blot analysis of cytoplasmic extract (50 $\mu \mathrm{g}$ of protein) with anti- $\alpha-L-A F$ antibodies

Lane St., ${ }^{14} \mathrm{C}$-labelled proteins standards: myosin (200000), phosphorylase $b(97400)$, BSA (69000), ovalbumin (46000), carbonic anhydrase (30000), trypsin inhibitor (21500) and lysozyme (14300); lane A, S. lividans 1326 (wild-type); lane B, S. lividans IAF10-164 (cer, $x / n^{-}$mutant); lane C, S. lividans IAF116 (abfA); lane D, pure AF (1 $\mu \mathrm{g}$ of protein).

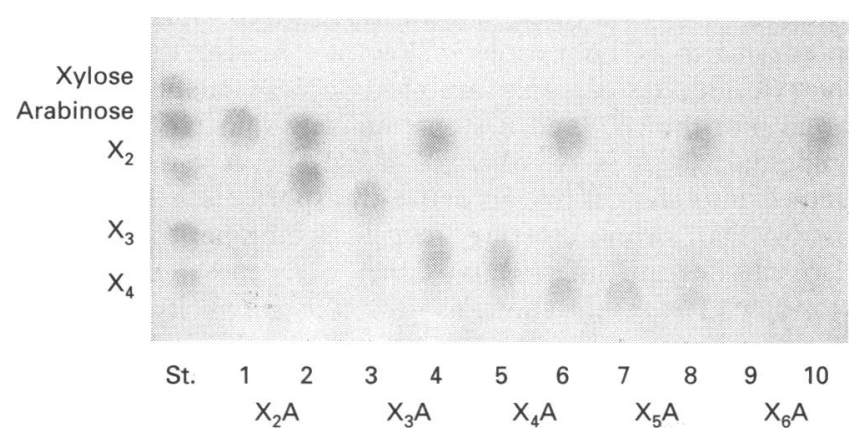

Figure 5 T.I.C. analysis of $\alpha$-L-AF activity on arabino-oligoxylosides

Lane St., standard sugars: xylose, arabinose, xylobiose $\left(X_{2}\right)$, xylotriose $\left(X_{3}\right)$, xylotetraose $\left(X_{4}\right)$; lane 1, arabino-xylobiose $\left(X_{2} A\right)$; lane 2, $X_{2} A$ hydrolysed with $A F$; lane 3 , arabinoxylotriose $\left(X_{3} A\right)$; lane $4, X_{3} A$ hydrolysed with $A F$; lane 5 , arabinoxylotetraose $\left(X_{4} A\right)$; lane $6, X_{4} A$ hydrolysed with $A F$; lane 7 , arabinoxylopentaose $\left(X_{5} A\right)$; lane $8, X_{5} A$ hydrolysed with $A F$; lane 9, arabinoxylohexaose $\left(X_{6} A\right)$; lane $10, X_{6} A$ hydrolysed with AF.

the AF activity was intracellular and was recovered in the cytoplasmic fraction obtained after centrifugation. In all, $90 \%$ of the activity was recovered in the protein precipitate between 35 and $65 \%$ saturation with $\left(\mathrm{NH}_{4}\right)_{2} \mathrm{SO}_{4}$. On phenyl-Sepharose CL-4B column chromatography, the bulk of the protein was eluted before the the AF activity, which was recovered at the end of the $\left(\mathrm{NH}_{4}\right)_{2} \mathrm{SO}_{4}$ gradient. The AF activity loaded on to an h.p.l.c. DEAE anion-exchange column was eluted at an $\mathrm{NaCl}$ concentration of $0.26 \mathrm{M}$. On h.p.l.c. gel-filtration chromato- graphy, the AF activity was eluted as a single peak. The approximate $M_{\mathrm{r}}$ of this protein was $380 \mathrm{kDa}$, estimated by h.p.l.c. gel filtration on Superose columns. The purity of the $\alpha$ L-AF was verified by SDS/PAGE followed by silver staining (Figure 3). A summary of the purification steps is shown in Table 2.

The AFs produced by clones IAF 112 and 113 were also purified and showed the same enzyme characteristics as those found for $S$. lividans IAF 116. However, in the case of IAF 113, the purified protein lacked several amino acid residues at the $\mathrm{C}$ terminal end of the molecule.

\section{Characterization of the $\alpha-L-A F$}

The cloned $\alpha$-L-AF from $S$. lividans IAF116 was compared with that of S. lividans 1326 and IAF10-164. SDS/PAGE and Western immunoblotting with anti-AF antibodies showed the identity of the purified enzyme with that of the wild-type (Figure 4). AF was not detectable in the mutant IAF10-164. This confirmed the lack of activity observed for this strain. SDS/PAGE analysis indicated that the purified protein had an apparent $M_{\mathrm{r}}$ of about 69000 . This is supported by an $M_{\mathrm{r}}$ of 72492 calculated from the DNA and amino acid sequence analysis. From gel chromatography the $M_{\mathrm{r}}$ of the protein was estimated to be about 380000 , which suggests that the native AF has a polymeric nature.

Analytical isoelectric focusing of the enzyme on a $\mathrm{pH}$ gradient from 3.0 to 10.0 indicated a $\mathrm{pI}$ of 4.6. The AF has an optimum activity at $60^{\circ} \mathrm{C}$ and at $\mathrm{pH} 6.0$. The enzyme when incubated without substrate was stable at $4{ }^{\circ} \mathrm{C}$ for $12 \mathrm{~h}$ at pH 6.0 . At $68^{\circ} \mathrm{C}$ and pH 6.0 the half-life was $12 \mathrm{~min}$. Periodate/Schiff staining indicated that the protein was not glycosylated.

The determination of the kinetic constants of the purified $\alpha-\mathrm{L}$ AF was carried out on $p$-nitrophenyl $\alpha$-L-arabinofuranoside at substrate concentrations between 0.1 and $1.0 \mathrm{mM}$. Under optimal assay conditions at $\mathrm{pH} 6.0$ and $60^{\circ} \mathrm{C}$ and using either the Lineweaver-Burk or the Eadie-Hofstee plots, resulted in a $V_{\max }$. of 180 units $/ \mathrm{mg}$ of enzyme and a $K_{\mathrm{m}}$ of $0.6 \mathrm{mM}$.

Towards $p$-nitrophenyl $\alpha$-L-arabinofuranoside the purified AF displayed high specific activity of 153 units $/ \mathrm{mg}$. A faint $\beta$-xylosidase activity of $0.18 \mathrm{unit} / \mathrm{mg}$ of protein was observed with $p$-nitrophenyl $\beta$-D-xylopyranoside. Other $p$-nitrophenyl saccharides with sugar moieties such as $\alpha$-L-arabinopyranose, $\beta$-D-glucose, $\beta$-D-galactopyranose, $\beta$-D-cellobiose or $\alpha$-L-mannopyranose were not affected. No end-product inhibition was evident when the purified AF was assayed in the presence of up to $50 \mathrm{mM}$ L-arabinose. No release of sugars could be detected when the enzyme was incubated with either oat-spelts xylan or arabinogalactan. Arabinose release was detected by h.p.l.c. analysis when the AF was incubated with debranched or linear beet arabinan and with rye- or wheat-flour arabinoxylans (results not shown). However, the AF hydrolysed arabino-oligoxylosides to arabinose and the corresponding oligoxyloside (Figure 5). 
These saccharides had been obtained from xylanase digest of oat spelts xylan and purified by column and paper chromatography, ranging from arabino-xylobiose to the arabinohexaxyloside.

\section{DISCUSSION}

The $\alpha$-l-AF gene of $S$. lividans was cloned by functional complementation in the previously described mutant $S$. lividans IAF10-164 (Mondou et al., 1986). This mutant, which does not express either the xylanase or the cellulase genes, was also unable to produce $\alpha$-AF activity. The use of the multicopy vector pIJ702 permitted the overproduction of the enzyme, reaching 48 times that of the wild-type strain $S$. lividans 1326 . This increase in gene expression facilitated significantly the purification of the enzyme. The overexpression is also consistant with the previously reported results for the genes cloned with the same system from $S$. lividans encoding for the xylanases A, B and C (Mondou et al., 1986; Kluepfel et al., 1990, 1992), the cellulases A and B (Théberge et al., 1992; Wittmann et al., 1994), as well as for a $\beta$-mannanase (Arcand et al., 1993). AFs play an important role in the degradation of the many arabinose-containing hemicelluloses. In conjunction with acetylxylan esterase, $\alpha$-methylglucuronidase and xylanases, their action is required as debranching enzyme for the complete biodegradation of xylans which are found in Nature in various heteropolymeric forms (Biely, 1985). Although AFs are found in many plants, fungi and bacteria, comparatively few have been cloned, purified and characterized. The heterologous cloning approach, using Escherichia coli, has been used to clone the AF-encoding genes from Pseudomonas fluorescens (Kellett et al., 1990), Butyrivibrio fibrisolvens (Utt et al., 1991), Clostridium stercorarium (Schwarz et al., 1990) and, more recently, for Aspergillus niger (Flipphi et al., 1993).

The DNA sequence of the $a b f \mathrm{~A}$ gene and its deduced amino acid sequence of the enzyme were determined. No significant similarity was found with the $x y n C$ gene of $P$. fluorescens, which encodes the XylC protein or with the $x y / \mathrm{B}$ gene of $B$. fibrisolvens. Both encode a bifunctional protein which exhibited both $\beta$ xylosidase and an $\alpha-\mathrm{AF}$ activities. The $S$. lividans enzyme has a low activity on $p$-nitrophenyl $\beta$-D-xylopyranoside, but does not act on xylan. Most $\alpha$-AFs exist in Nature as monomers, but dimers, tetramers and octamers have also been reported. Their $M_{\mathrm{r}}$ values range from 53000 to 495000 (Eriksson et al., 1990). From the estimated $M_{\mathrm{r}}$ of 380000 the $S$. lividans enzyme in its natural form appears to consist also of several subunits. The enzyme is located inside the cells and was purified from the cytoplasmic fraction during the exponential growth of the microorganism (up to $72 \mathrm{~h}$ ). It is also released, after prolonged fermentation, into the culture filtrate in its natural form, possibly as a result of cell lysis. Attempts to purify the protein from the supernatant were unsuccessful, owing to a pigment that copurified and interfered consistently with the isolation.

The $\alpha$-L-AF was produced by submerged cultures in Erlenmeyer flasks containing a simple mineral-salts medium with oat-spelts xylan. Under these conditions the wild-type strain $S$. lividans 1326 produced 0.05 unit/mg of protein. The clone $S$. lividans IAF116 containing the $a b f A$ gene on the multicopy plasmid produced under the same conditions 2.41 units, corresponding to a 48 -fold increase in enzyme production. This production level is amongst the highest reported in the literature (Kaji et al., 1981 ; Komae et al., 1982; Greve et al., 1984; Lee and Forsberg 1987; Hespell and O'Bryan, 1992; Tajana et al., 1992).

DNA sequence and $\mathrm{N}$-terminal amino acid analysis of the enzyme indicated the absence of a signal peptide, which confirmed the intracellular location of protein. AFs purified from actino- mycetes such as $S$. diastaticus (Tajana et al., 1992), Streptomyces sp. 17-1 (Kaji et al., 1981) and S. purpurascens (Komae et al., 1982) were all recovered from culture supernatants. While the first enzymes isolated after only $24 \mathrm{~h}$ of incubation appeared likely to have been secreted, the latter two, of high $M_{r}(>92000)$ were isolated in the later stages (more than 4 days), possibly released during cell lysis. The biochemical characteristics of the $S$. lividans AF are similar to those reported for many of the enzymes isolated from both eukaryote and prokaryote origins (Hespell and O'Bryan, 1992). The specific activity of the enzyme from $S$. lividans is 153 units/mg of protein, significantly higher than those of streptomycetes reported elsewhere.

A comparison of specificities on natural substrates of the characterized AFs shows subtle differences. Thus the enzyme from Streptomyces sp. 17-1 hydrolyses arabinan, arabinoxylan or arabinogalactan (Kaji et al., 1981), whereas the AF from $S$. purpurascens is inactive towards these substrates, but is active on low- $M_{\mathrm{r}}$ oligoarabinosides (Komae et al., 1982). $S$. diastaticus produces two enzymes that attack oat-spelts xylan and arabinan (Tajana et al., 1992). The $S$. lividans AF described here exhibits no activity on oat-spelts xylan and arabinogalactan. It acts slowly on arabinan and arabinoxylan from wheat and rye flour by releasing L-arabinofuranose after prolonged incubation (overnight). However, the enzyme hydrolyses rapidly the shortchain arabino-oligoxylosides prepared by digestion of oat-spelts xylan with xylanases. Owing to the difficulty of preparing sufficient quantities of these compounds in pure form, testing of these substrates had to be limited to arabinoxylosides containing two to six xylose moieties as backbone substituted with one arabinose molecule. From these results and from the hydrolysis patterns obtained with the different $p$-nitrophenyl derivatives, the $S$. lividans enzyme can be classified among the $\alpha$-L-AFs (EC 3.2.1.55).

The substrate specificity of the AF of S. lividans is likely correlated with its intracellular location, which limits access to the enzyme to carbohydrates of low $M_{\mathrm{r}}$. Among the arabinooligoxylosides tested, only arabinoxylobiose might be transported into the cell, and it seems unlikely that the larger size compounds $\left(X_{3} A-X_{6} A\right.$, where $X=X y l$ and $\left.A=A r a\right)$ can be pumped into the cell by an active-transport mechanism. It is possible that, before crossing the cell membrane, the arabinooligoxylosides are affected by either a xylanase or by a $\beta$ xylosidase. The results show also that this specificity is characteristic and remains unchanged, even when AF is released into the culture filtrates during the idiophase of the fermentation. It remains to be established whether the enzyme retains a role in the microbial metabolism at this stage.

This research was supported by a grant from the Natural Sciences and Engineering Research Council of Canada (NSERC) under the Co-operative University-Industry Program. We also thank Nicole Daigneault and Liette Biron for their excellent technical assistance.

\section{REFERENCES}

Arcand, N., Kluepfel, D., Paradis, F. W., Morosoli, R. and Shareck, F. (1993) Biochem. J. 290, 857-863

Biely, P. (1985) Trends Biotechnol. 3, 286-290

Brice, R. E. and Morrison, J. M. (1982) Carbohydr. Res. 101, 93-100

Brillouet, J. M., Moulin, J. C. and Agosin, E. (1985) Carbohydr. Res. 144, 113-126

Dekker, R. F. H. and Richards, G. N. (1976) Adv. Carbohydr. Chem. Biochem. 32, 277-352

Eriksson, K. E. L., Banchette, R. A. and Ander, P. (1990) Microbial and Enzymatic Degradation of Wood and Wood Components, Springer-Verlag, Berlin

Flipphi, M. J. A., Visser, J., van der Veen, P. and de Graaff, L. H. (1993) Appl. Microbiol. Biotechnol. 39, 335-340

Greve, L. C., Labavitch, J. M. and Hungate, R. E. (1984) Appl. Environ. Microbiol. 47, 1135-1140

Gunata, Y. Z., Biron, C., Sapis, J. C. and Bayonove, C. (1989) Vitis 28, 191-197 
Hespell, R. B. and O'Bryan, P. J. (1992) Appl. Environ. Microbiol. 58, 1082-1088 Hopwood, D. A., Bibb, M. J., Chater, K. F., Kieser, T., Bruton, C. J., Kieser, H. M., Lydiate, D. J., Smith, C. P., Ward, J. M. and Schrempt, H. (1985) Genetic Manipulations of Streptomyces: A Laboratory Manual, The John Innes Foundation, Norwich John, M., Trénel, G. and Dellweg, H. (1969) J. Chromatogr. 42, 476-484 Kaji, A. (1984) Adv. Carbohydr. Chem. Biochem. 42, 383-397

Kaji, A. and Yoshihara, 0. (1970) Agric. Biol. Chem. 34, 1249-1253

Kaji, A., Tagawa, K. and Ichimi, T. (1969) Biochim. Biophys. Acta 171, 186-188

Kaji, A., Sato, M. and Tsutsui, Y. (1981) Agric. Biol. Chem. 45, 925-931

Katz, E., Thompson, C. J. and Hopwood, D. A. (1983) J. Gen. Microbiol. 129, 2703-2714

Kellett, L. E., Poole, D. M., Ferreira, L. M. A., Durrant, A. J., Hazlewood, G. P. and Gilbert, H. J. (1990) Biochem. J. 272, 369-376

Kluepfel, D., Vats-Mehta, S., Aumont, F., Shareck, F. and Morosoli, R. (1990) Biochem. J. 267, $45-50$

Kluepfel, D., Daigneault, N., Morosoli, R. and Shareck, F. (1992) Appl. Microbiol. Biotechnol. 36, 626-631

Komae, K., Kaji, A. and Sato, M. (1982) Agric. Biol. Chem. 46, 1899-1905

Lee, S. F. and Forsberg, C. W. (1987) Can. J. Microbiol. 33, 1011-1016

Lowry, O. H., Rosebrough, N. J., Farr, A. L. and Randall, R. J. (1951) J. Biol. Chem. 193, 265-275

Mondou, F., Shareck, F., Morosoli, R. and Kluepfel, D. (1986) Gene 49, 323-329

Poutanen, K. (1988) J. Biotechnol. 7, 271-282
Rombouts, F. M., Voragen, A. G. J., Searle-van Leewen, M. F., Geraeds, C. C. J. M., Schols, H. A. and Pilnik, W. (1988) Carbohydr. Polym. 9, 25-47

Sambrook, J., Fritsh, E. F. and Maniatis, T. (1989) Molecular Cloning: A Laboratory Manual, Cold Spring Harbor Laboratory Press, Cold Spring Harbor, NY

Sanger, F., Nicklen, S. and Coulson, A. R. (1977) Proc. Natl. Acad. Sci. U.S.A. 74, 5463-5467

Schwarz, W. H., Adelsberger, H., Jauris, S., Hertel, C., Funk, B. and Staudenbauer, W. L. (1990) Biochem. Biophys. Res. Commun. 170, 368-374

Shareck, F., Mondou, F., Morosoli, R. and Kluepfel, D. (1987) Biotechnol. Lett. 9, 160-174

Shareck, F., Roy, C., Yaguchi, M., Morosoli, R. and Kluepfel, D. (1991) Gene 107, 75-82

Tajana, E., Fiechter, A. and Zimmermann, W. (1992) Appl. Environ. Microbiol. 58, $1447-1450$

Théberge, M., Lacaze, P., Shareck, F., Morosoli, R. and Kluepfel, D. (1992) Appl. Environ. Microbiol. 58, 815-820

Utt, E. A., Eddy, C. K., Keshav, K. F. and Ingram, L. 0. (1991) Appl. Environ. Microbiol. 57, 1227-1234

Ward, O. P. and Moo-Young, M. (1989) CRC Crit. Rev. Biotechnol. 8, 237-274

Weinstein, L. and Albersheim, P. (1979) Plant Physiol. 63, 425-432

Wittmann, S., Shareck, F., Kluepfel, D. and Morosoli, R. (1994) Appl. Environ. Microbiol. 60, 1701-1703

Wong, K. K. Y., Tan, L. U. L. and Saddler, J. N. (1988) Microbiol. Rev. 52, 305-317

Wright, F. and Bibb, M. J. (1992) Gene 113, 55-65

Received 17 December 1993/7 March 1994; accepted 25 March 1994 